\title{
Noncoding RNAs in cancer therapy resistance and targeted drug development
}

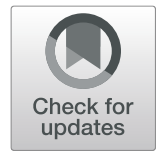

Wen-Tao Wang ${ }^{1 \dagger}$, Cai Han ${ }^{1 \dagger}$, Yu-Meng Sun ${ }^{1}$, Tian-Qi Chen ${ }^{1}$ and Yue-Qin Chen ${ }^{1,2^{*}}$

\begin{abstract}
Noncoding RNAs (ncRNAs) represent a large segment of the human transcriptome and have been shown to play important roles in cellular physiology and disease pathogenesis. Increasing evidence on the functional roles of ncRNAs in cancer progression emphasizes the potential of ncRNAs for cancer treatment. Here, we summarize the roles of ncRNAs in disease relapse and resistance to current standard chemotherapy and radiotherapy; the current research progress on ncRNAs for clinical and/or potential translational applications, including the identification of ncRNAs as therapeutic targets; therapeutic approaches for ncRNA targeting; and ncRNA delivery strategies in potential clinical translation. Several ongoing clinical trials of novel RNA-based therapeutics were also emphasized. Finally, we discussed the perspectives and obstacles to different target combinations, delivery strategies, and system designs for ncRNA application. The next approved nucleic acid drug to treat cancer patients may realistically be on the horizon.
\end{abstract}

Keywords: ncRNA, Chemoresistance, Radioresistance, Therapeutic approaches, Delivery strategies, Translational application

\section{Background}

Cancer is an unconquered disease that generally causes mortality and morbidity worldwide and generates many adverse socioeconomic effects. Although proteinrelevant therapeutics such as antibodies against Programmed Cell Death 1 (PD1), programmed death-ligand 1 (PDL1), and cytotoxic T-lymphocyte-associated protein 4 (CTLA-4) have driven a revolutionary trend in pharmacotherapy and drug development, some protein targets encoded by oncogenes are undruggable or inadequate for achieving remission, and cancer cells can acquire drug resistance [1]. Therefore, the treatment of cancer further requires multiple types of targets involved in oncogenic pathways for successful intervention.

To advance the understanding of cancer initiation and progression, many genomic and proteomic approaches have been developed [1-3]. The landscape of genomic mutations in cancer reveals that many mutations or copy number changes in cancer are frequently located in

\footnotetext{
* Correspondence: Isscyq@mail.sysu.edu.cn

WTW and $\mathrm{CH}$ equally contributed to the study

${ }^{1}$ MOE Key Laboratory of Gene Function and Regulation, State Key Laboratory for Biocontrol, Sun Yat-sen University, Guangzhou 510275, China

${ }^{2}$ School of Life Science, Sun Yat-sen University, Guangzhou 510275, People's Republic of China
}

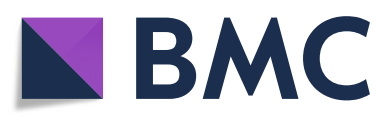

(๑) The Author(s). 2019 Open Access This article is distributed under the terms of the Creative Commons Attribution 4.0 International License (http://creativecommons.org/licenses/by/4.0/), which permits unrestricted use, distribution, and

reproduction in any medium, provided you give appropriate credit to the original author(s) and the source, provide a link to the Creative Commons license, and indicate if changes were made. The Creative Commons Public Domain Dedication waiver (http://creativecommons.org/publicdomain/zero/1.0/) applies to the data made available in this article, unless otherwise stated.

noncoding DNA regions [1, 4]. Noncoding DNA has been reported to cover $95 \%$ of DNA sequences in the human genome, most of which are transcribed into tens of thousands of functional noncoding RNAs (ncRNAs), including microRNAs (miRNAs), small interfering RNAs (siRNAs), antisense RNAs (asRNAs), and long noncoding RNAs (lncRNAs) [4-7]. Recent studies have also reported a novel type of ncRNA, circular RNA (circRNA) [8-10]. A large portion of circRNAs are generated from exons of coding genes, and most do not express protein [8-10]. The biogenesis of several kinds of ncRNAs, such as miRNA [1, 2, 5], short hairpin RNA (shRNA) and siRNA [11], IncRNA [4], and circRNA [8-10], is summarized in Fig. 1. Accumulating evidence shows that ncRNAs are dysregulated and implicated in various cancer processes, such as cancer stem cell (CSC) initiation, metastasis, and drug resistance, highlighting the role of ncRNAs as potential therapeutic targets in cancer $[5,6,8-15]$. Several miRNAs have reached clinical trials [15-17]. In addition, IncRNAs and circRNAs have demonstrated significant clinical relevance in cancers due to their relatively complex and diverse structures and functions acting through multiple mechanisms $[6,8]$. 


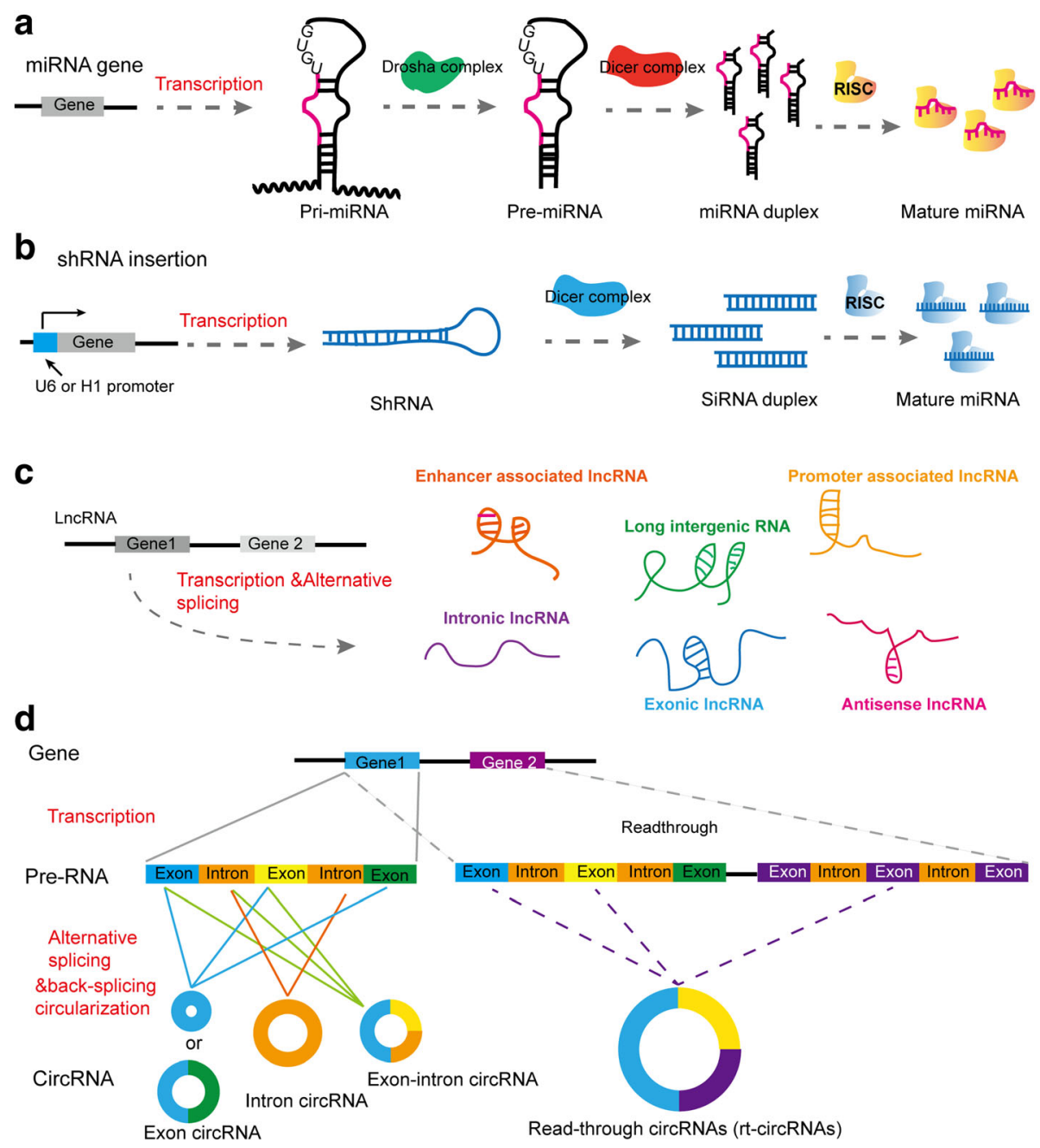

Fig. 1 The biogenesis of several kinds of ncRNAs. a Most of miRNA genes are transcribed by Pol II and produce greater than 200-nt pre-miRNAs, which contain at least one hairpin structure harboring the miRNA sequence. In the nucleus, the pre-miRNAs are cleaved into approximately 70nucleotide pre-miRNAs with a stem-loop structure by Drosha, an RNAse III enzyme. The pre-miRNAs are subsequently exported to the cytoplasm and then cleaved by another RNAse III enzyme, Dicer. Finally, the $\sim 22$ miRNA duplex was loaded into RISC and the mature single-stranded miRNA guides RISC to recognize mRNA targets. $\mathbf{b}$ The endogenous siRNA can be derived from shRNA. The transcription of shRNA gene is driven by a U6 or $\mathrm{H} 1$ promoter. ShRNA are then cleaved by Dicer to form mature 21 siRNAs that subsequently are loaded into RISC. c LncRNAs are pervasively transcribed in the genome. According to the origins of transcription sites, IncRNAs can be summarized into different types, including enhancer-associated IncRNA, promoter-associated IncRNA, exonic and intronic IncRNA, long intergenic IncRNA, and antisense IncRNA. d Schematic representation of circRNA generation. Most of circRNAs are derived from pre-mRNAs and characteristic of spliceosome-dependent. CircRNA can be classified into various types, including exon circRNA, intron circRNA, and extron-intron circRNA. A novel type circRNA, called read-through circRNA (rtcircRNA), has been identified (marked in dotted line). The rt-circRNA is circularized from read-through transcripts

Moreover, the preclinical studies and increased success rates of nucleic acid therapeutics provide an opportunity to target ncRNAs for cancer treatment $[5,15-17]$.

Here, we summarize ncRNAs in therapeutic resistance, the potential as therapeutic targets, the current status of ongoing clinical trials, and therapeutic approaches for targeting ncRNAs. We also discuss the challenges for the efficient delivery of ncRNAs as therapeutics, the obstacles in clinical trials, and the perspective for the future design of nucleic acid therapeutics.

\section{NcRNAs in cancer therapy resistance NcRNAs in cancer chemoresistance}

The development of resistance to anticancer drugs is a major challenge in cancer therapy, generally causing relapse and even mortality in patients $[18,19]$. Despite the complex mechanism underlying chemosensitivity and chemoresistance, ncRNAs are increasingly appreciated to overcome this obstacle. Figure $2 \mathrm{a}$ represents the known ncRNAs in cancer therapy resistance and the regulatory network of different kinds of ncRNAs 


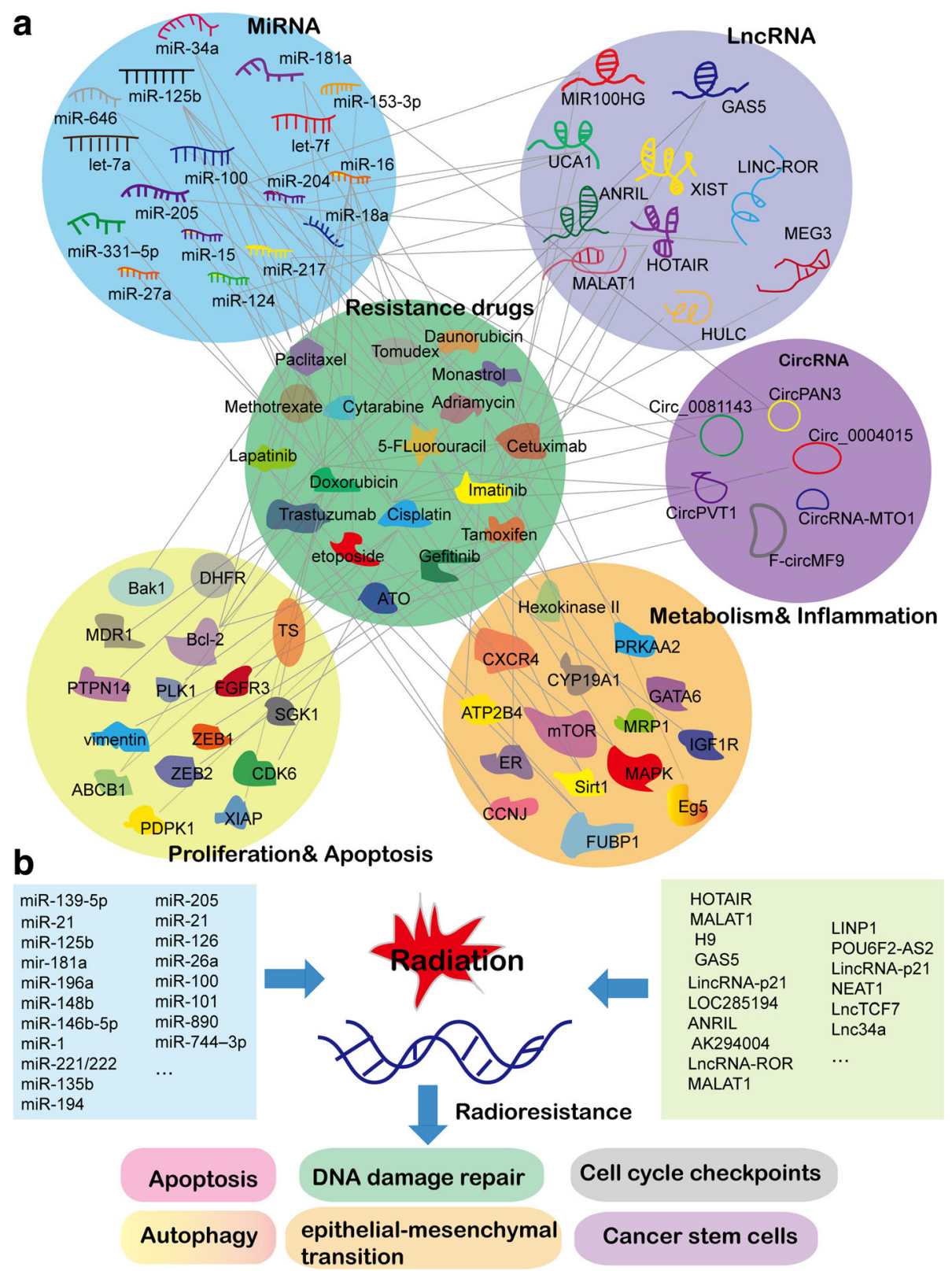

Fig. 2 NcRNAs in cancer therapy resistance. a The network of miRNA, IncRNA, and circRNA in chemoresistance and the drug resistance pathways. b ncRNAs play a part in cancer radioresistance and concomitantly promote various events in the recurrence and metastasis of malignant tumors, including apoptosis, DNA damage repair, cell cycle checkpoints, autophagy, epithelial-mesenchymal transition, and cancer stem cells

involved in chemoresistance and the related drug resistance pathways.

\section{MiRNA}

MiRNAs are the most extensively studied ncRNAs in terms of chemoresistance or chemosensitivity [20], and some miRNAs exhibit double-faced roles in mediating the sensitivity of various tumors to different drugs [20$25]$. An example is $m i R-125$, which has been reported to resist drug therapy in various cancers [21, 22]. This
miRNA confers paclitaxel resistance to breast cancer cells through suppressing the expression of the proapoptotic protein Bcl-2 antagonist killer 1 (Bak1) [22]; in addition, it can reduce the expression of dihydrofolate reductase $(D H F R)$ and thymidylate synthase (TS) to promote the resistance of colon cancer and osteosarcoma to the drugs methotrexate or Tomudex [23]. However, the expression of $m i R-125 b$ was also found to negatively correlate with 5 -fluorouracil resistance in hepatocarcinoma [25]. The double-faced roles of miRNAs highlighted the 
necessity of thorough laboratory investigation of antimiRNA drugs before proceeding to clinical trials [25].

$M i R-181 a$ is another example that mediates chemosensitivity. In patients with acute myeloid leukemia (AML) treated with similar intensive induction therapy regimens, a higher expression level of miR-181a was strongly correlated with complete remission (CR) [26]. Restoration of miR-181a levels by ectopic expression of artificial mimics reversed chemoresistance to cytarabine and daunorubicin in AML cell lines [27, 28]. Notably, lenalidomide, a drug in current clinical use, can induce the expression of miR-181a and therefore may be a possible therapeutic intervention for chemoresistant patients [29]. Other miRNAs, such as let-7, miR-128, miR331, miR-10, and miR-27a, have also been shown to overcome chemoresistance in AML [30-33]. However, clinical datasets for these miRNAs are lacking or sometimes show contradictory results, necessitating larger cohort analyses. It should be noted that clinical correlation of ncRNAs with chemosensitivity does not necessarily guarantee the functional relevance of ncRNAs in drug resistance. Functional experiments assessing the effects of ncRNA modulation are essential.

\section{LnCRNA}

LncRNA is another class of ncRNAs that has been linked to resistance to certain drugs in certain types of cancers $[34,35]$. For example, blocking HOX transcript antisense RNA (HOTAIR) considerably decreased the expression of multidrug resistance-associated protein 1 (MRP1) and inactivated the PI3K/Akt signaling pathway, resulting in improved sensitivity to imatinib treatment $[34,35]$. Another study reported that HOTAIR is upregulated in tamoxifen-resistant breast cancer tissues and that is restored upon the blockade of estrogen receptor (ER) signaling either by hormone deprivation or by tamoxifen treatment, leading to ligand-independent ER activity and tamoxifen resistance in breast cancer [36]. Thus, HOTAIR can be considered a potential therapeutic target for the reversal of resistance to conventional chemotherapeutics in patients with different types of cancer. In addition, Zhu et al. found that X-inactive specific transcript (XIST) regulated doxorubicin (DOX) resistance possibly through regulating the miR-124/SGK1 axis and that XIST knockdown enhanced the antitumor effect of DOX in colorectal cancer (CRC) in vivo, providing insights into developing therapeutic strategies to overcome chemoresistance in CRC patients [37]. These findings show that lncRNAs are indeed closely related to chemoresistance, shedding new light on valuable therapeutic strategies against cancer.

\section{CircRNA}

The roles of circRNAs in chemoresistance have been demonstrated recently. For example, hsa_circ_0001258 upregulated GSTM2 expression through sponging miR744-3 $p$ to promote chemoresistance in osteosarcoma [38]. Hsa_circ_0081143 knockdown induced cisplatin sensitivity in gastric cancer cells in vitro and in in vivo mouse models through releasing miR-646 to downregulate CDK6 expression [39]. In addition, hsa_circ_ 0004015 regulated the resistance of non-small cell lung cancer cells to tyrosine kinase inhibitors (TKIs) by targeting the miR-1183/PDPK1 pathway [40]. Furthermore, overexpression of the fusion circRNA $f$-circMF9 prominently increased the resistance of mouse $M L L-A F 9$ leukemia cells to arsenic trioxide (ATO) treatment in vivo [41]. Similar to IncRNAs, circRNAs may have opportunities to act as therapeutic targets for chemoresistance; however, additional investigation and testing are required.

\section{NcRNAs in cancer radioresistance}

In addition to their roles in chemoresistance, ncRNAs play a part in radiosensitivity as summarized in Fig. 2b. As tumor cells generally impair DNA damage repair ability and have the propensity for more rapid division, these cells are more prone to apoptosis induced by radiation than normal tissues [42]. However, several findings have implied that radiotherapy might concomitantly promote the recurrence and metastasis of malignant tumors by activating epithelial-mesenchymal transition (EMT) and/or generating CSCs [43, 44]; importantly, ncRNAs are closely involved in these processes.

Several studies have revealed the strong relation between the expression patterns of a subgroup of miRNAs with the radiotherapy response in various cancers, including non-small cell lung cancer, head and neck tumors, squamous cell carcinoma, and squamous cervical carcinoma [45-48]. Thus, these miRNAs could be predictors of radioresistance (Fig. 2b, left panel). For example, Marina et al. found that several target genes of $m i R-139-5 p$ were strongly predictive of outcome in radiotherapy-treated patients, suggesting that this miRNA may be a potentially useful predictive biomarker of radioresistance in breast cancer [46]. Besides, some miRNA expression levels change in a unique pattern during radiotherapy treatment. Thus, miRNAs can also be used as monitors to evaluate the real-time response to radiotherapy and to prevent delays in changing to an alternative treatment regimen [49-51]. The reported "circulating miRNAs" and plasma lncRNAs or lncRNAs such as HOTAIR, metastasis-associated lung adenocarcinoma transcript 1 (MALAT1), H19, and GAS5 might also have value in the evaluation of radioresistance in cancer patients [52-55].

Mechanically, ncRNAs acting as modulators of radiosensitivity are mainly through regulating the processes of apoptosis, DNA damage repair, and EMT [52, 56]. For 
example, miR-21, miR-125b, miR-181a, miR-196a, and miR-148b suppress the expression of the apoptosisrelated genes caspase-3, intercellular adhesion molecule2 (ICAM-2), Protein Kinase C Delta (PRKCD), annexin A1 (ANXA1), or DNA methyltransferase 3b (DNMT3B) in a wide spectrum of cancers [56]. LncRNAs, such as LincRNA-p21, LOC285194, ANRIL, AK294004, LncRNA$R O R$, and $M A L A T 1$, can regulate apoptosis-related genes either by binding to the protein partners or by acting as competing endogenous RNAs (ceRNAs) [57-59] (Fig. $2 \mathrm{~b}$, right panel). Some lncRNAs could also modulate radioresistance by regulating the DNA damage response [56, 60, 61]. For instance, IncRNA LINP1 can enhance repair of DNA double-strand breaks by serving as a scaffold linking Ku80 and DNA-dependent protein kinase catalytic subunit (DNA-PKcs). Blocking LINP1 increases the sensitivity of the tumor-cell response to radiotherapy in breast cancer [61]. Furthermore, many EMT- and CSC-related lncRNAs are also responsible for radioresistance [62-64]. MALAT1 is the one reported to promote radioresistance through triggering EMT and CSC activity $[63,64]$. Silencing the expression of MALAT1 sensitizes nasopharyngeal carcinoma cells to radiotherapy both in vitro and in vivo through the inactivation of EMT and CSCs by modulating the miR-1/SLUG axis [64]. Some other lncRNAs, such as LincRNA-p21, NEAT1, LncTCF7, and $L n c 34 a$, might also affect radiotherapy responses [65-67]. These findings highlight the effects of ncRNAs on CSCs and radioresistance, supporting the design of effective strategies to improve radiotherapy responses.

\section{NcRNAs as therapeutic targets}

In addition to the involvement of ncRNAs in therapy resistances as discussed above, numerous ncRNAs have also shown potential as therapeutic targets because of their differential expression patterns between cancerous and normal tissues and their important roles in carcinogenesis [2, 5, 68-70]. With advances in nanotechnology, numerous clinical trials on RNA-guided precision medicine have recently been developed and/or are ongoing $[2,16,71]$. As summarized in Table 1, among the annotated ncRNAs, miRNAs are the most extensively investigated. MiRNAs function as either oncogenes or tumor suppressors, which, in turn, cause aberrant translational inhibition or degradation of their target mRNAs [72]. The pivotal double-faced roles of miRNAs in cancer make them as both therapeutic candidates and the direct therapeutic targets [17]. MiRNA mimics and antimiRNAs are two major therapeutic forms used to mimic the function of endogenous tumor suppressor miRNAs and to deplete oncogenic miRNAs, respectively [73, 74]. For instance, $m i R-34 a$ mimic was the first miRNA-based therapy to be introduced into the clinic [16]. MiR-34a can antagonize many different oncogenic processes by silencing oncogenes, including cyclin-dependent kinase 4/ $6(C D K 4 / 6)$, SIRT1, and SOX2, which function in selfrenewal, migratory potential, and chemoresistance in various types of cancers $[16,75,76]$. In a phase I clinical trial, researchers designed a liposomal nanoparticle to deliver corresponding $m i R-34 a$ mimics to the liver and precisely target cancer tissues [77]. More excitingly, many clinical trials of miRNA-based therapeutics have reached phase 3 or 4 ( https://clinicaltrials.gov), suggesting the promise of these therapeutic targets in precision medicine. Screenings of miRNA-based drugs have identified specific miRNA targets in different cancers, including $m i R-31-3 p$ and $m i R$ $31-5 p$ in colorectal cancer (CRC) [78], and miR-21 and $m i R-200$ in oral cancer $[79,80]$. The ongoing clinical trials have indicated that miRNA could be a widespread target in cancer treatment.

Apart from the extensively studied miRNAs, lncRNAs and circRNAs have recently emerged as novel targets $[6$, 8, 9, 68]. Compared with miRNAs, IncRNAs and circRNAs act through more diverse mechanisms in carcinogenesis [4, 81, 82]; thus, targeting lncRNAs and circRNAs provides varied means to modulate a range of critical processes in cancer development. Doublestranded RNA-mediated interference (RNAi) and singlestranded antisense oligonucleotides (ASOs) are two major approaches to target lncRNAs. ASOs can reduce the levels of oncogenic isoforms of lncRNAs by regulating alternative splicing, modulating RNA-protein interactions, or causing IncRNA degradation [83, 84]. For example, targeting lncRNA MALAT1 with ASO induced differentiation and inhibited metastasis in a mouse model of breast cancer $[84,85]$. The antimetastatic effect of MALAT1 targeting by ASO was also reported in a lung cancer xenograft model, highlighting the potential of MALAT1 as a therapeutic target in multiple tumors [86]. Notably, a subset of IncRNAs named natural antisense RNAs (NATs) are sometimes located near important tumor suppressors, such as ANRIL and p21-AS [87, 88]. Therapeutic inhibition of cis-acting NATs with a special type of ASO, antagoNATs, can potentially upregulate the overlapping tumor suppressor genes; thus, modulating lncRNA expression could be a tool to regulate gene expression. However, therapeutic targeting of lncRNAs and circRNAs remains mainly at the laboratory stage.

\section{Therapeutic approaches for targeting ncRNAs in cancers}

Approaches for therapeutic targeting are essential for precision medicine. Several preclinical studies have been initiated to investigate anticancer strategies for targeting oncogenic ncRNAs (https://clinicaltrials.gov). Three strategies have been proposed: ASOs, locked nucleic acids (LNAs), and morpholinos [1, 89-94]. ASOs are 
Table 1 Ongoing clinical trials of non-coding RNAs in cancer (ClinicalTrials.gov)

\begin{tabular}{|c|c|c|c|c|}
\hline NcRNA & NCT number & Clinical trials & Cancer & Phases \\
\hline $\begin{array}{l}\text { miR-31 } \\
\text { miR-210 }\end{array}$ & NCT03684707 & $\begin{array}{l}\text { Cancer chemoprevention by metformin } \\
\text { hydrochloride compared to placebo in } \\
\text { oral potentially malignant lesions }\end{array}$ & Oral cancer & Phase 4 \\
\hline $\begin{array}{l}\operatorname{miR}-31-3 p \\
\text { miR-31-5p }\end{array}$ & NCT03362684 & $\begin{array}{l}\text { PETACC-8 miR-31-3p and miR-31-5p } \\
\text { ancillary study }\end{array}$ & Colorectal Cancer & Phase 3 \\
\hline miR-34a & NCT02862145 & $\begin{array}{l}\text { Pharmacodynamics study of MRX34, } \\
\text { microRNA liposomal injection in } \\
\text { melanoma patients with biopsy } \\
\text { accessible lesions }\end{array}$ & Melanoma & $\begin{array}{l}\text { Phase } 1 \\
\text { Phase } 2\end{array}$ \\
\hline miR-34a & NCT01829971 & $\begin{array}{l}\text { A multicenter phase I study of MRX34, } \\
\text { microRNA miR-RX34 liposomal injection }\end{array}$ & $\begin{array}{l}\text { Primary liver cancer, SCLC, lymphoma, } \\
\text { multiple myeloma, renal cell carcinoma }\end{array}$ & Phase 1 \\
\hline miR-10b & NCT01849952 & $\begin{array}{l}\text { Evaluating the expression levels of } \\
\text { microRNA-10b in patients with gliomas }\end{array}$ & Glioma & Recruiting \\
\hline miR-29b & NCT02009852 & $\begin{array}{l}\text { Observational study to explore the } \\
\text { prognostic value of miR-29b in tissue, } \\
\text { blood, and saliva }\end{array}$ & Oral cancer & Recruiting \\
\hline miR-29 family & NCT01927354 & $\begin{array}{l}\text { Observational study to investigate the } \\
\text { role of microRNA in Twist1-mediated } \\
\text { cancer metastasis }\end{array}$ & Head and neck squamous cell carcinoma & Recruiting \\
\hline miRNA-100 & NCT02950207 & $\begin{array}{l}\text { Prospective observational study of } \\
\text { antitumor activity correlation between } \\
\text { hormonal therapy and expression } \\
\text { miRNA100 }\end{array}$ & Breast cancer & Recruiting \\
\hline MiR-155 & NCT03591367 & $\begin{array}{l}\text { The potential role of microRNA-155 } \\
\text { and telomerase reverse transcriptase in } \\
\text { diagnosis of non-muscle invasive } \\
\text { bladder cancer and their pathological } \\
\text { correlation }\end{array}$ & Bladder cancer & Recruiting \\
\hline miR-16 & NCT02369198 & $\begin{array}{l}\text { MesomiR 1: a phase I study of TargomiRs } \\
\text { as } 2 \text { nd or 3rd line treatment for patients } \\
\text { with recurrent MPM and NSCLC }\end{array}$ & $\begin{array}{l}\text { Malignant pleural mesothelioma, } \\
\text { non-small cell lung cancer }\end{array}$ & Phase 1 \\
\hline $\begin{array}{l}\text { miR-21 } \\
\text { miR-20a-5 } \\
\text { miR-103a-3p } \\
\text { miR-106b-5p } \\
\text { miR-143-5p } \\
\text { miR-215 }\end{array}$ & NCT02466113 & $\begin{array}{l}\text { A } 6 \text { microRNA tool for stratifying stage } \\
\text { II colon cancer of receiving adjuvant } \\
\text { chemotherapy }\end{array}$ & Colon cancer & Recruiting \\
\hline $\begin{array}{l}\text { miR-221 } \\
\text { miR-222 }\end{array}$ & NCT02928627 & $\begin{array}{l}\text { Clinical significance of hepatic and } \\
\text { circulating microRNAs miR-221 and } \\
\text { miR-222 in hepatocellular carcinoma }\end{array}$ & Hepatocellular carcinoma & Recruiting \\
\hline miR-122 & NCT03687229 & $\begin{array}{l}\text { The effect of DAAs on miRNA-122 and } \\
\text { insulin resistance in chronic HCV patients }\end{array}$ & $\begin{array}{l}\text { Chronic hepatitis C, hepatocellular } \\
\text { carcinoma }\end{array}$ & Not yet recruiting \\
\hline MiR-25 & NCT03432624 & $\begin{array}{l}\text { Detection of microRNA- } 25 \text { in the } \\
\text { diagnosis of pancreatic cancer }\end{array}$ & Carcinoma, pancreatic ductal & Not yet recruiting \\
\hline HOTAIR & NCT03469544 & $\begin{array}{l}\text { Long non-coding RNA HOTAIR and } \\
\text { Midkine as biomarkers in thyroid cancer }\end{array}$ & Thyroid cancer & Recruiting \\
\hline THRIL,PACER & NCT03057171 & $\begin{array}{l}\text { A study on the gastrointestinal disease } \\
\text { and helicobacter pylori controlled long } \\
\text { non-coding RNA }\end{array}$ & Stomach cancer & Recruiting \\
\hline
\end{tabular}

single-stranded oligonucleotides that have specific complementarity to target sequences to promote target RNA degradation by RNase $\mathrm{H}$ as shown in Fig. 3(a) [91]. LNAs are also single-stranded oligonucleotides containing a stretch of DNA flanked by LNA nucleotides and offer specific complementarity and RNase $\mathrm{H}$-mediated degradation of the target sequence as shown in Fig. 3(b)
[92, 93]. Different from ASOs and LNAs, morpholino oligonucleotides (MO) are 25-nt nonionic DNA analogs used to promote RNA degradation through binding target RNAs in diverse organisms (Fig. 3(c)) [94-97]. These strategies have been applied for targeting oncogenic ncRNAs in cancer. For instances, miR-10b ASOs together with a low dose of doxorubicin showed a 


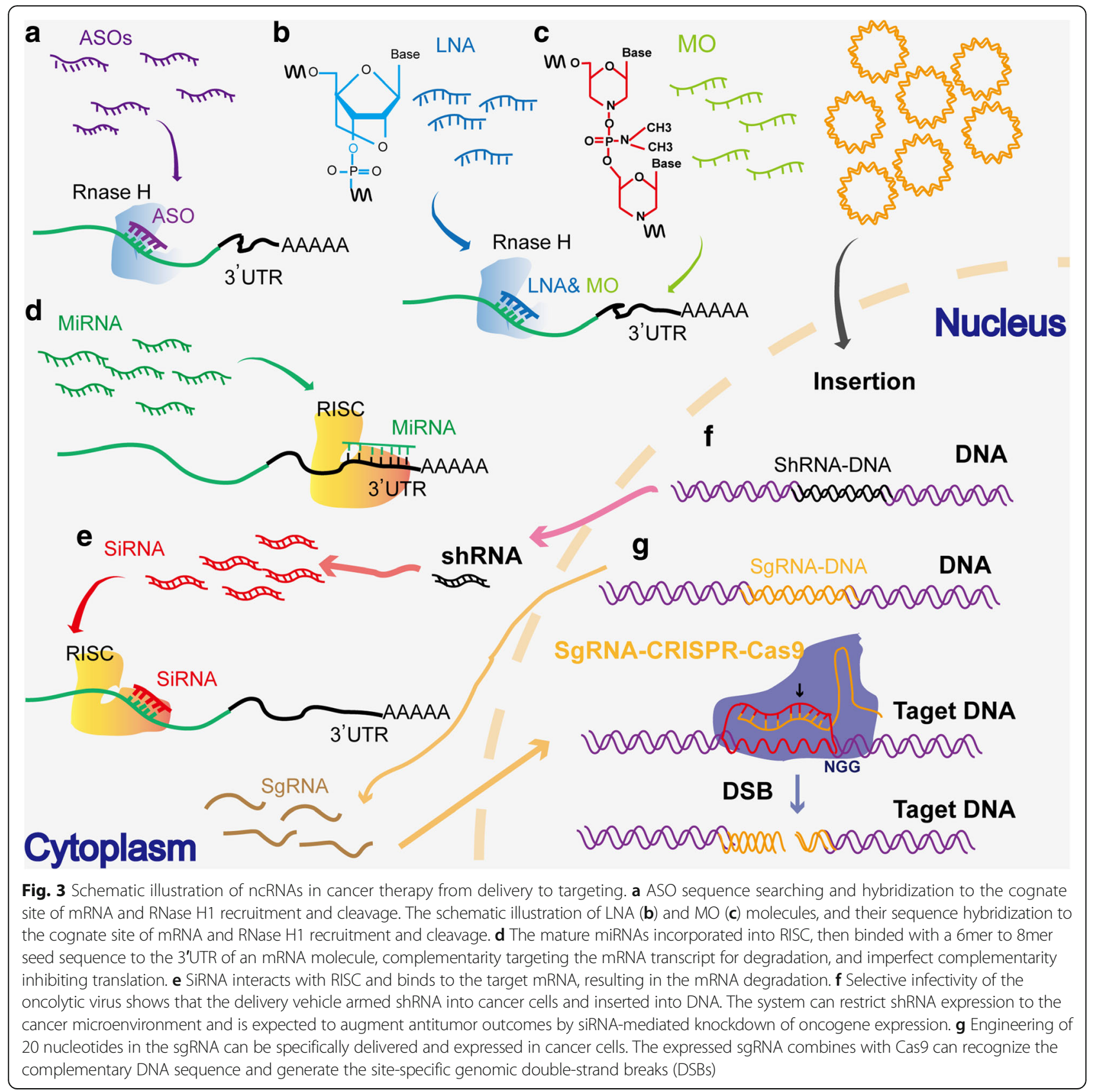

significant decrease in tumor size compared with the results only using doxorubicin monotherapy to treat breast cancer in mouse models [98]. The researchers also applied $m i R-10 b$ LNAs for investigation and found that miR-10b LNAs can enhance the sensitivity of breast cancer to doxorubicin in mouse models, with no additional damage to normal tissue, suggesting low toxicity associated with the delivery of this LNA nanoparticle [98]. MALAT1 ASOs could also inhibit the metastasis of cancer cells and the tumor burden in mice [99]. AVI-4126, a morpholinosbased drug, was used to inhibit $c-M Y C$ translation in a sequence-specific manner by simultaneously blocking the expressions of $c-M Y C$ and causing the mis-splicing of its pre-mRNA, resulting in significant growth inhibition in various cancer cells, such as prostate cancer, breast cancer, and lung cancer $[95,97,100]$. Chang et al. designed a phosphorodiamidate morpholino oligomer that effectively silenced miR-487a in a mouse model and reduced tumor growth and metastasis [96]. These studies indicate that morpholinos-based drugs of targeting oncogenic ncRNAs may represent a promising approach for cancer therapy. Further clinical trials are required. 


\section{Small ncRNAs as a therapeutic tool in cancer treatment}

With unique properties in their chemical behavior, modes of action and clinical pharmacokinetics, ncRNAs have been considered not only as the therapeutic targets, but also as an alternative promising therapeutic tool for cancer treatment. This possibility is especially meaningful for small ncRNAs, including miRNAs (Fig. 3(d)) [2], siRNAs, shRNA (Fig. 3(e, f)) [101], small activating RNAs (saRNAs) [7], guide RNAs (gRNAs) (Fig. 3(g)) [102], and other forms of small RNAs (sRNAs) [1, 6].

SiRNA is a well-studied small ncRNA tested for preclinical trials. SiRNAs are a class of synthetic short double-stranded RNAs with 21 base pairs that are recruited by the RNA-induced silencing complex (RISC) in cells and silence the expression of their target mRNAs, lncRNAs, or circRNAs by complementary base pairing (Fig. 3(e)) [101, 103]. Zorde et al. developed a system for local prolonged effects of siRNA (Local Drug EluteR, LODER) enabling the utilization of siRNAs against mutated Kirsten rat sarcoma (KRAS) (siG12D LODER) [104]. Mutated KRAS has been reported to be resistant to small molecule drugs that target oncogenic proteins. They found that siG12D LODER suppressed the growth of human pancreatic cancer cells in vivo and therefore prolonged mouse survival [104]. In an openlabel phase $1 / 2 \mathrm{a}$ study, an improved therapeutic effect was reported in patients with locally advanced pancreatic cancer (LAPC) treated with a combination regimen of siG12D-LODER and gemcitabine [105]. Some other siRNA-based drugs have already completed phase II clinical trials as shown in Table 2, including DCR-MYC for $M Y C$ knocking down to arrest cell growth in hepatocellular carcinoma (HCC) (NCT02314052), Atu027 for PKN3 knocking down to regulate cell migration in metastatic pancreatic adenocarcinoma (NCT01808638), etc. The rapid development of siRNA- and miRNA-based clinical trials profits from the shortness of small RNA sequences and technical advances in previously introduced delivery carriers. These advantages facilitate enduring and safe circulation in the blood and ease of uptake by target cells to improve the biodistribution and bioavailability of these RNAs during trafficking to cancer cells.

saRNA is another type of small double-stranded ncRNA designed to target gene promoters to activate transcription and thus upregulate gene expression [7]. In a preclinical trial, Reebye et al. designed a saRNA targeting $C E B P A$ that can activate the transcription of $C / E B P$ $\alpha$ in a liver cancer model [106]. They found that intravenous injection of $C / E B P \alpha$-saRNA reduced the tumor burden and suppressed the expression of interleukin (IL) 6R and c-Myc and inhibited STAT3 phosphorylation [106]. The delivery efficiency was improved by loading
$C / E B P \alpha$-saRNA in a liposomal nanoparticle in the following clinical trial study [107]. The ongoing clinical trial indicated that saRNAs are promising for activating the transcription of tumor suppressor.

gRNA is also an important type of small ncRNAs. Since the discovery of the clustered regularly interspaced short palindromic repeats (CRISPR)-CRISPR-associated (Cas) system, Cas-gRNA-based biotechnology has developed rapidly and massively (Fig. 3(g)) [102, 108]. Diverse RNA-programmable CRISPR-Cas enzymes have been gradually found and subsequently applied to reverse the aberrant expression of oncogenes and tumor suppressor genes [102]. Generally, the CRISPR-Cas system has two advantages over other gene editing strategies. First, the CRISPR-Cas system offers sequence-specific DNA targeting through a single-guide RNA (sgRNA)-based nucleoprotein complex that specifically cleaves the genomic DNA of interest to accomplish gene editing and mutation. Second, designing the sgRNA sequence targeting the desired DNA sequence is simple and flexible. Due to the great advantages of the sgRNA-guided CRISPR-Cas system, CRISPR systems have been widely adapted to facilitate the discovery of new targets in cancer therapy. For example, Yamauchi et al. performed a genome-wide CRISPR-Cas9 screen in AML cell lines to identify novel targets for AML therapy and discovered that the mRNA decapping enzyme scavenger (DCPS) gene, which is involved in pre-mRNA metabolic pathways, is essential for AML cell survival [109]. More interestingly, these researchers further found that germline biallelic DCPS loss-of-function mutations resulted in failure to induce leukemogenesis in humans, suggesting that CRISPR-Cas9-mediated silencing of DCPS is a potential strategy for AML therapy [109]. In addition, recent applications of the CRISPR-Cas system in chimeric antigen receptor (CAR) $\mathrm{T}$ cells, including CD133specific CAR $T$ cells with PD-1 deficiency and CD3specific CAR T cells with diacylglycerol kinase (DGK) deficiency $[110,111]$, have been shown to be promising strategies in cancer immunotherapy. Although most studies exploring the CRISPR-Cas system are still in the preclinical stage, multiple Cas-based clinical trials are in progress or will be commencing soon.

\section{NcRNA delivery strategies for potential translational application}

Although small ncRNAs have been shown to be promising and effective therapeutic drugs in vitro, the low bioavailability of these nucleic acid drugs in vivo is a major challenge $[6,73,94]$. Thus, the development of advanced drug delivery strategies is urgently needed. To overcome the general problems of a short half-life, off-target effects and low transfection efficiency in RNA delivery, various small ncRNA carriers or systems have been 
Table 2 Ongoing clinical trials with identified siRNAs in cancer (ClinicalTrials.gov.)

\begin{tabular}{|c|c|c|c|c|}
\hline $\begin{array}{l}\text { SiRNA } \\
\text { targets }\end{array}$ & NCT number & Title & Cancer & Phases \\
\hline VEGF & NCT00306904 & $\begin{array}{l}\text { Safety and efficacy study of small interfering RNA } \\
\text { molecule (Cand5) to treat diabetic macular edema }\end{array}$ & Diabetic macular edema & Phase 2 \\
\hline MYC & NCT02314052 & $\begin{array}{l}\text { Phase Ib/2, multicenter, dose escalation study of } \\
\text { DCR-MYC in patients with hepatocellular carcinoma }\end{array}$ & Hepatocellular carcinoma & $\begin{array}{l}\text { Phase } 1 \\
\text { Phase } 2\end{array}$ \\
\hline $\begin{array}{l}\text { PD-L1 } \\
\text { PD-L2 }\end{array}$ & NCT02528682 & $\begin{array}{l}\text { MiHA-loaded PD-L-silenced DC vaccination after } \\
\text { allogeneic SCT }\end{array}$ & Hematological malignancies & $\begin{array}{l}\text { Phase } 1 \\
\text { Phase } 2\end{array}$ \\
\hline $\begin{array}{l}\text { Mutated } \\
\text { KRAS }\end{array}$ & NCT01676259 & $\begin{array}{l}\text { A phase } 2 \text { study of siG12D LODER in combination } \\
\text { with chemotherapy in patients with locally } \\
\text { advanced pancreatic cancer }\end{array}$ & $\begin{array}{l}\text { Pancreatic ductal adenocarcinoma pancreatic } \\
\text { cancer }\end{array}$ & Phase 2 \\
\hline PKN3 & NCT01808638 & $\begin{array}{l}\text { Atu027 plus gemcitabine in advanced or metastatic } \\
\text { pancreatic cancer (Atu027-I-02) }\end{array}$ & Carcinoma, pancreatic ductal & $\begin{array}{l}\text { Phase } 1 \\
\text { Phase } 2\end{array}$ \\
\hline EphA2 & NCT01591356 & $\begin{array}{l}\text { EphA2 gene targeting using neutral liposomal small } \\
\text { interfering RNA delivery }\end{array}$ & Advanced cancers & Phase 1 \\
\hline $\begin{array}{l}\text { LMP2 } \\
\text { LMP7 } \\
\text { MECL1 }\end{array}$ & NCT00672542 & $\begin{array}{l}\text { Immunotherapy of melanoma with tumor antigen } \\
\text { RNA and small inhibitory RNA transfected } \\
\text { autologous dendritic cells }\end{array}$ & $\begin{array}{l}\text { Metastatic melanoma } \\
\text { Absence of CNS metastases }\end{array}$ & Phase 1 \\
\hline APN401 & NCT02166255 & $\begin{array}{l}\text { APN401 in treating patients with melanoma, } \\
\text { kidney cancer, pancreatic cancer, or other solid } \\
\text { tumors that are metastatic or cannot be removed } \\
\text { by surgery }\end{array}$ & $\begin{array}{l}\text { Recurrent melanoma } \\
\text { Recurrent pancreatic cancer } \\
\text { Recurrent renal cell cancer } \\
\text { Stage III/IV pancreatic cancer } \\
\text { Stage III renal cell cancer } \\
\text { Stage IIIA/B/C/IV Melanoma } \\
\text { Stage IV renal cell cancer }\end{array}$ & Phase 1 \\
\hline PLK1 & NCT01437007 & TKM 080301 for primary or secondary liver cancer & $\begin{array}{l}\text { Colorectal cancer with hepatic metastases } \\
\text { Pancreas cancer with hepatic metastases } \\
\text { Gastric cancer with hepatic metastases } \\
\text { Breast cancer with hepatic metastases } \\
\text { Ovarian cancer with hepatic metastases }\end{array}$ & Phase 1 \\
\hline M2 & NCT00689065 & $\begin{array}{l}\text { Safety study of CALAA-01 to treat solid tumor } \\
\text { cancers }\end{array}$ & Solid tumor & Phase 1 \\
\hline AHR & NCT01075360 & $\begin{array}{l}\text { The role of aromatic hydrocarbon receptor in the } \\
\text { tumorigenesis of neuroblastoma and its relationship } \\
\text { with MYCN expression }\end{array}$ & Neuroblastoma & Recruiting \\
\hline B4GALNT3 & NCT01058798 & $\begin{array}{l}\text { The role of glycosyltransferases in the oncogenesis } \\
\text { of neuroblastoma }\end{array}$ & Neuroblastoma & Recruiting \\
\hline$B C L-B$ & NCT01270009 & Role of BCL-B in multiple myeloma & Multiple myeloma & $\begin{array}{l}\text { Not yet } \\
\text { recruiting }\end{array}$ \\
\hline
\end{tabular}

proposed and extensively investigated, including nanoparticles (Fig. 4a), ncRNA modification (Fig. 4b, c), and oncolytic adenovirus strategy (Fig. 4d).

The first class of carriers is nanoparticle-based and includes self-assembled oligonucleotide nanoparticles [112], lipid-based nanoparticles (LNPs) [113], inorganic nanoparticles, and polymeric nanoparticles [101]. Huang et al. reported the assembly of a calcium-phosphatelipid nanoparticle, which showed higher efficiency in delivering siRNA into HCC cells than into normal hepatocytes [114]. These lipid nanoparticles were subsequently loaded with VEGF siRNAs and downregulated VEGF expression specifically in $\mathrm{HCC}$ both in vitro and in vivo, exhibiting a potent antiangiogenic effect in the tumor microenvironment in a mouse model of HCC [115]. This carrier spectrum is also reflected in the miRNA monotherapies used in several types of cancers-for example, $m i R-34$ and $m i R-125 b$ in non-small cell lung cancer $[116,117], m i R-212$ and $m i R-216 b$ in pancreatic ductal adenocarcinoma $[118,119], m i R-328$ in CRC [120], and $m i R-221$ in liver cancer [121]. Several clinical trials for siRNA-/miRNA-based therapeutics targeting cancers have been performed (Fig. 3(d, e)).

NcRNA modification is another effective strategy to improve the precision and durability of small ncRNAs in targeting genes of interest in cancer, including siRNAs chemically conjugated with carriers forming carriersiRNA conjugates (Fig. 4b) and siRNAs modified with lipid and PEG molecules, and then self-assembled lipid nanoparticles named as SAMiRNA (Fig. 4c). In developing therapy for liver cancer, two cooperative groups have chemically conjugated special siRNAs with (2-3) $N$-acetylgalactosamine (GalNAc) and developed GalNacconjugated siRNAs [122]. GalNAc is a type of ligand 


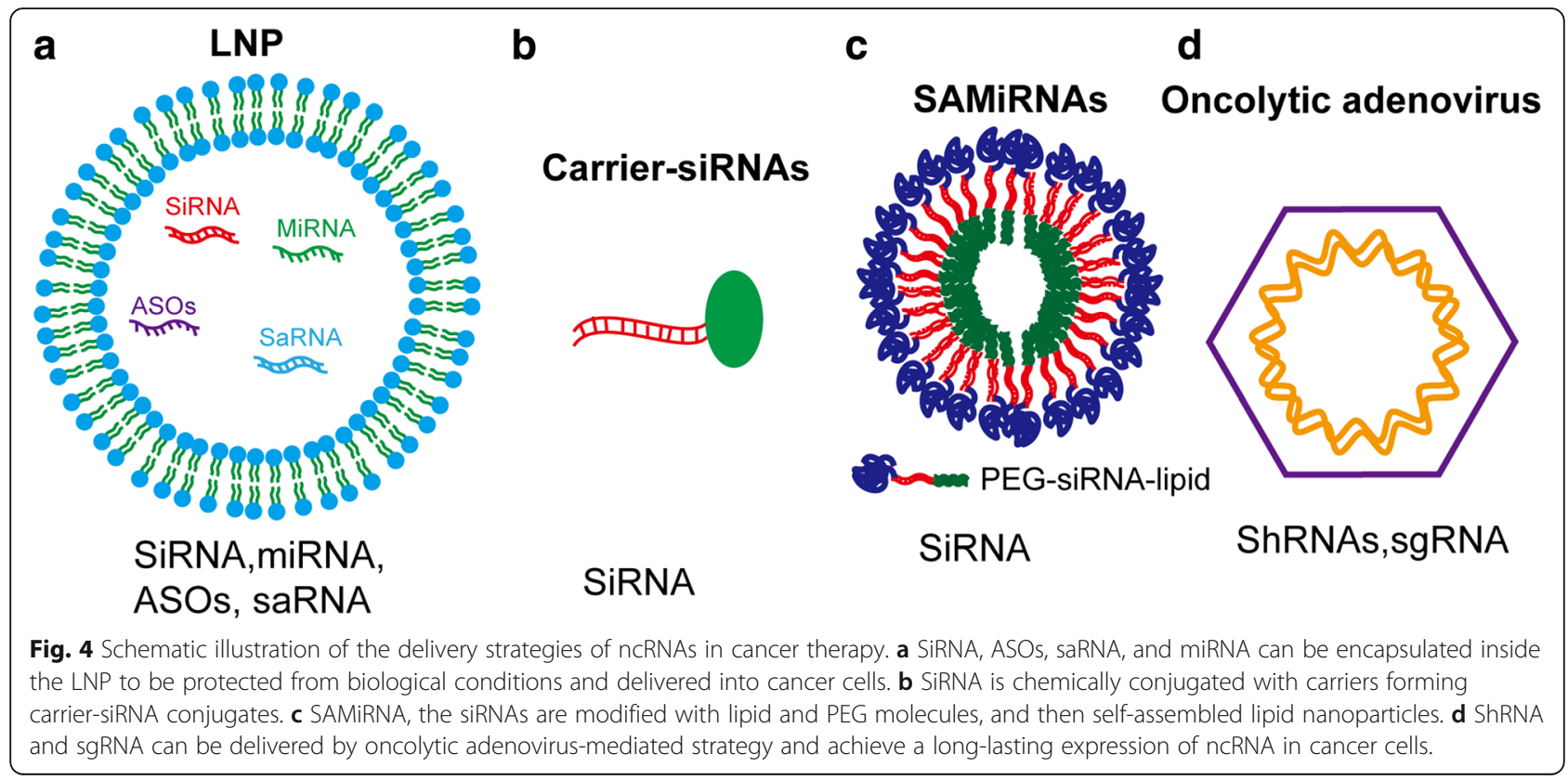

with high binding affinity to the asialoglycoprotein receptor (ASGPR), which is specifically expressed and localized on the surface of hepatocytes. Martin et al. demonstrated that the interaction of ASGPR with the GalNAc ligand facilitates clathrin-mediated endocytosis [123]. Finally, most GalNac-conjugated siRNAs could be precisely delivered into the lesions of HCC and form RISC complexes to degrade target mRNAs [122]. Currently, the developed GalNAc-siRNA conjugates are undergoing clinical trials. The team subsequently refined this siRNA by optimizing the positioning of the 2'-deoxy-2'-fluoro and 2'-O-methyl ribosugar modifications to enhance stability without compromising the intrinsic RNAi activity, yielding significantly improved potency and duration in preclinical species [124]. Another challenge is the cytotoxicity induced by delivery carriers such as cationic liposomes, which can trigger pulmonary inflammation and the production of reactive oxygen intermediates [125]. For instance, siRNAs conjugated to the cell-penetrating peptide (CPP) TAT(48-60) indeed exhibited improved gene silencing efficiency. However, this conjugate also concomitantly activates the innate immune response [126]. Modification of siRNAs with hypotoxicity is also a problem requiring a solution. Yoon et al. developed SAMiRNAs by conjugating siRNAs to hydrophilic polymers and lipids to form conjugates (Figs. $4 \mathrm{c}$ and 3 (e)) [112]. SAMiRNAs can be specifically delivered into tumor tissue with high stability and have high knockdown efficiency. The advantage of this method is that the induction of cytokines in mouse peripheral blood mononuclear cells (PBMCs) and the levels of toxicity in liver and kidneys were below the relevant detection limits [112].
The methods described above are based on transient transfection of dsRNA. However, effective siRNA targeting for therapeutic purposes would require sustaining effects of gene silencing on oncogenic RNAs of interest. The emergence of a stable RNA silencing strategy via oncolytic adenovirus has introduced a revolutionary advance in cancer therapy [127]. The oncolytic adenoviral vector is designed to remove the partial sequences of the $E 1 A$ gene region to render the adenovirus replicative exclusively in cancer cells [127]. Thus, compared to conventional therapy, this engineered adenovirus showed reduced toxicity and achieved promising results (Figs. $4 \mathrm{~d}$ and 3(f, g)) [127-130] . The oncolytic adenoviral vector allows the insertion of large numbers of different genes with various DNA sequence lengths, including human genes, shRNA sequences, and CRISPR-Cas9 sequences. We consider Ad-shRNA as an example. Machitani et al. developed a telomerase-specific replication-competent adenovirus (TRAD), which carries the tumor-specific promoter-driven $E 1$ gene expression cassette and exhibits increased replication efficiency and antitumor activity [130]. This group loaded shRNA targeting Dicer into the TRAD. After infection, TRAD-shDicer efficiently induced Dicer knockdown and exhibited significantly higher replication efficiency and prodeath activity in tumor cells than in normal cells [130]. Continued progress in the development of oncolytic adenovirus strategies might allow this approach to be an important and powerful alternative tool to treat cancer.

\section{Conclusions and perspectives}

NcRNAs are emerging as crucial players in tumorigenesis. Recent progress in biotechnologies such as high- 
throughput sequencing, genome editing, mouse modeling, and pharmaceutical chemistry has allowed functional studies of ncRNAs to provide a new perspective for waging the war against cancer. In addition to miRNAs and lncRNAs, other novel ncRNAs, such as transfer RNA (tRNA) fragments, snoRNA-related IncRNAs (snolncRNAs), and circRNAs, have also begun to appear on the radar of cancer researchers. Notably, snoRNAs have regained attention in cancer research, and snoRNA derivatives might be potential players in cancer development. The tissue-specific expression of ncRNAs makes them exciting candidates for molecular targeting. Additional ncRNA targets for cancer treatment are expected to be discovered in subsequent studies. However, because ncRNAs vary in length and modes of action, the development of systematic genomic and functional approaches will be needed to better understand the roles of ncRNAs and to evaluate their potential as therapeutic targets.

As chemotherapy and radiotherapy remain the mainstream treatment approaches for cancer patients, the roles of ncRNAs in mediating chemo- and radioresistance will be increasingly appreciated. Although a subgroup of ncRNAs - to date, miRNAs and lncRNAs, in particularhave proven to be useful biomarkers for predicting treatment outcomes or monitoring therapeutic responses, most studies are still in the preclinical stage. In addition, only a few of these ncRNAs exist stably in body fluid, thus enabling a noninvasive liquid biopsy approach. More efforts are needed to discover additional circulating ncRNAs for convenient clinical diagnosis. Notably, the results of some studies evaluating the potential of ncRNAs as biomarkers are conflicting. Larger cohorts of clinical data should be mined to reconcile these controversies.

Not only are ncRNAs promising targets for treating cancer and modulating cancer treatment sensitivity, approaches for targeting ncRNAs could be RNA-based. The rapid evolution of nucleic acid therapeutics offers an exceptional opportunity to explore ncRNAs as druggable targets in the clinic. MiRNA mimics and modified miRNAs/siRNAs are currently major RNA-based drugs that target mRNAs and ncRNAs. Other methods, such as ASOs, morpholinos, and small molecules, are also promising approaches via the modulation of ncRNA degradation, alternative splicing, and RNA-protein interactions. The CRISPR-CAS system represents another prospective method, but much additional study is needed for its eventual application in the clinic. Despite the enthusiasm, several obstacles still need to be overcome. First, delivery technologies with increased efficiency should be developed; crossing the cell membrane remains the foremost issue. The complex internal microenvironment makes the delivery and application of ncRNA difficult, including RNA degradation and instability, off-target, and low transfection efficiency.
Development of more advanced delivery strategy is urgency. The combination of two or more carriers may be a good choice for ncRNA targeting, such as combination of nanodesigns with organ-specific response receptor may improve the precision and efficiency of drug delivery. Second, identifying a means to evade nuclease degradation or innate immune system targeting is critical for increasing bioavailability. Last but not least, minimal off-target effects and toxicity should be ensured. Despite these challenges, nucleic acid therapeutics might be powerful drugs for cancer treatment.

\section{Abbreviations \\ AML: Acute myeloid leukemia; ANXA1: Annexin A1; \\ ASGPR: Asialoglycoprotein receptor; ASOs: Antisense oligonucleotides; asRNAs: Antisense RNAs; ATO: Arsenic trioxide; Bak1: Bcl-2 antagonist killer 1; CAR: Chimeric antigen receptor; Cas: CRISPR associated; CDK4/6: Cyclin- dependent kinase 4/6; ceRNAs: Competing endogenous RNAs; circRNA: Circular RNA; CRC: Colorectal cancer; CRISPR: Interspaced short palindromic repeats; CSC: Cancer stem cell; CTLA-4: Cytotoxic T-lymphocyte- associated protein 4; DCPS: Decapping enzyme scavenger; \\ DHFR: Dihydrofolate reductase; DNA-PKCS: DNA-dependent protein kinase catalytic subunit; DOX: Doxorubicin; EMT: Epithelial-mesenchymal transition; gRNAs: Guide RNAs; HCC: Hepatocellular carcinoma; HOTAIR: HOX transcript antisense RNA; ICAM-2: Intercellular adhesion molecule-2; KRAS: Mutated Kirsten rat sarcoma; LAPC: Locally advanced pancreatic cancer; LNAs: Locked nucleic acids; IncRNAs: Long noncoding RNAs; LNPs: Lipid-based \\ nanoparticles; MALAT1: Metastasis-associated lung adenocarcinoma transcript 1; miRNAs: MicroRNAs; MO: Morpholino oligonucleotides; MRP1: Multidrug resistance-associated protein 1; NATs: Natural antisense RNAs; \\ ncRNAs: Noncoding RNAs; PBMCs: Peripheral blood mononuclear cells; PD1: Programmed cell death 1; PDL1: Programmed death-ligand 1; RISC: RNA-induced silencing complex; RNAi: RNA-mediated interference; saRNAs: Small activating RNAs; sgRNA: Single-guide RNA; shRNA: Short hairpin RNA; siRNAs: Small interfering RNAs; sno-IncRNAs: snoRNA-related IncRNAs; sRNAs: Small RNAs; TKIs: Tyrosine kinase inhibitors; \\ TRAD: Telomerase-specific replication-competent adenovirus; tRNA: Transfer RNA; TS: Thymidylate synthase; XIST: X-inactive specific transcript}

\section{Acknowledgements}

Not applicable.

\section{Authors' contributions}

Y-QC designed the study and drafted the manuscript. W-TW and CH prepared the tables and figures and drafted the manuscript. All authors participated in the process of drafting and revising the manuscript. All authors read and approved the final manuscript.

\section{Funding}

This research was supported by National Key R\&D Program of China (No. 2017YFA0504400) and National Natural Science Foundation of China (No. 81770174 and 31870818).

\section{Availability of data and materials}

The material supporting the conclusion of this review has been included within the article.

Ethics approval and consent to participate

Not applicable for this review.

Consent for publication

Not applicable for this review.

Competing interests

The authors declare that they have no competing interests. 


\section{Publisher's Note}

Springer Nature remains neutral with regard to jurisdictional claims in published maps and institutional affiliations.

Received: 23 April 2019 Accepted: 31 May 2019

Published online: 07 June 2019

\section{References}

1. Yu A, Jian C, Yu AH, Tu M. RNA therapy: are we using the right molecules? Pharmacol Ther. 2019;196:91-104

2. Hayes J, Peruzzi PP, Lawler S. MicroRNAs in cancer: biomarkers, functions and therapy. Trends Mol Med. 2014;20(8):460-9.

3. Li Y, Xu Q, Lv N, Wang L, Zhao H, Wang X, Guo J, Chen C, Li Y, Yu L. Clinica implications of genome-wide DNA methylation studies in acute myeloid leukemia. J Hematol Oncol. 2017:10(1):41.

4. Guttman M, Rinn JL. Modular regulatory principles of large non-coding RNAs. Nature. 2012;482(7385):339-46.

5. Esteller M. Non-coding RNAs in human disease. Nat Rev Genet. 2011;12(12): 861-74.

6. Matsui M, Corey DR. Non-coding RNAs as drug targets. Nat Rev Drug Discov. 2017;16(3):167-79.

7. Yoon S, Rossi JJ. Therapeutic potential of small activating RNAs (saRNAs) in Human Cancers. Curr Pharm Biotechnol. 2018;19(8):604-10

8. Dong Y, He D, Peng Z, Peng W, Shi W, Wang J, Li B, Zhang C, Duan C. Circular RNAs in cancer: an emerging key player. J Hematol Oncol. 2017; 10(1):2.

9. Li X, Yang L, Chen LL. The biogenesis, functions, and challenges of circular RNAs. Mol Cell. 2018;71(3):428-42.

10. Vo JN, Cieslik M, Zhang Y, Shukla S, Xiao L, Zhang Y, Wu YM, Dhanasekaran SM, Engelke CG, Cao X, Robinson DR, Nesvizhskii Al, Chinnaiyan AM. The landscape of circular RNA in cancer. Cell. 2019;176(4):869-81.

11. Timmons L. The long and short of siRNAs. Mol Cell. 2002;10(3):435-7.

12. Zhang $M$, Xin $Y$. Circular RNAs: a new frontier for cancer diagnosis and therapy. J Hematol Oncol. 2018;11(1):21.

13. Guo S, Fesler A, Wang H, Ju J. microRNA based prognostic biomarkers in pancreatic cancer. Biomark Res. 2018;6(1):18.

14. Fort RS, Mathó C, Oliveira-Rizzo C, Garat B, Sotelo-Silveira JR, Duhagon MA. An integrated view of the role of miR-130b/301b miRNA cluster in prostate cancer. Exp Hematol Oncol. 2018;7(1):10.

15. Smolle MA, Calin HN, Pichler M, Calin GA. Noncoding RNAs and immune checkpoints-clinical implications as cancer therapeutics. Febs J. 2017;284(13): 1952-66.

16. Bader AG. miR-34 - a microRNA replacement therapy is headed to the clinic. Front Genet. 2012:3:120.

17. Rupaimoole R, Slack FJ. MicroRNA therapeutics: towards a new era for the management of cancer and other diseases. Nat Rev Drug Discov. 2017:16(3): 203-22.

18. Diesch J, Zwick A, Garz AK, Palau A, Buschbeck M, Gotze KS. A clinicalmolecular update on azanucleoside-based therapy for the treatment of hematologic cancers. Clin Epigenetics. 2016:8:71.

19. Bainschab A, Quehenberger F, Greinix HT, Krause R, Wolfler A, Sill H, Zebisch A. Infections in patients with acute myeloid leukemia treated with lowintensity therapeutic regimens: risk factors and efficacy of antibiotic prophylaxis. Leuk Res. 2016;42:47-51.

20. Corra F, Agnoletto C, Minotti L, Baldassari F, Volinia S. The network of noncoding RNAs in cancer drug resistance. Front Oncol. 2018:8:327

21. Rothmiller S, Wolf M, Worek F, Steinritz D, Thiermann H, Schmidt A Alteration of miRNA expression in a sulfur mustard resistant cell line. Toxicol Lett. 2018:293(1):38-44.

22. Zhou M, Liu Z, Zhao Y, Ding Y, Liu H, Xi Y, Xiong W, Li G, Lu J, Fodstad O, Riker Al, Tan M. MicroRNA-125b confers the resistance of breast cancer cells to paclitaxel through suppression of pro-apoptotic $\mathrm{Bcl}-2$ antagonist killer 1 (Bak1) expression. J Biol Chem. 2010;285(28):21496-507.

23. Tang XY, Zheng $W$, Ding $M$, Guo K, Yuan F, Feng H, Deng B, Sun W, Hou Y, Gao L. miR-125b acts as a tumor suppressor in chondrosarcoma cells by the sensitization to doxorubicin through direct targeting the ErbB2-regulated glucose metabolism. Drug Des Devel Ther. 2016;10:571-83.

24. Rastgoo N, Abdi J, Hou J, Chang H. Role of epigenetics-microRNA axis in drug resistance of multiple myeloma. J Hematol Oncol. 2017;10(1):121

25. Yu X, Shi W, Zhang Y, Wang X, Sun S, Song Z, Liu M, Zeng Q, Cui S, Qu X. CXCL12/CXCR4 axis induced miR-125b promotes invasion and confers 5- fluorouracil resistance through enhancing autophagy in colorectal cancer. Sci Rep. 2017;7:42226.

26. Schwind S, Maharry K, Radmacher MD, Mrozek K, Holland KB, Margeson D, Whitman SP, Hickey C, Becker H, Metzeler KH, Paschka P, Baldus CD, Liu S, Garzon R, Powell BL, Kolitz JE, Carroll AJ, Caligiuri MA, Larson RA, Marcucci $\mathrm{G}$, Bloomfield CD. Prognostic significance of expression of a single microRNA, miR-181a, in cytogenetically normal acute myeloid leukemia: a cancer and leukemia group B study. J Clin Oncol. 2010;28(36):5257-64.

27. Bai H, Cao Z, Deng C, Zhou L, Wang C. miR-181a sensitizes resistant leukaemia HL-60/Ara-C cells to Ara-C by inducing apoptosis. J Cancer Res Clin Oncol. 2012;138(4):595-602.

28. Li H, Hui L, Xu W. miR-181a sensitizes a multidrug-resistant leukemia cell line K562/A02 to daunorubicin by targeting BCL-2. Acta Biochim Biophys Sin (Shanghai). 2012;44(3):269-77.

29. Hickey CJ, Schwind S, Radomska HS, Dorrance AM, Santhanam R, Mishra A, Wu YZ, Alachkar H, Maharry K, Nicolet D, Mrozek K, Walker A, Eiring AM, Whitman SP, Becker H, Perrotti D, Wu LC, Zhao X, Fehniger TA, Vij R, Byrd $J C$, Blum W, Lee LJ, Caligiuri MA, Bloomfield CD, Garzon R, Marcucci G. Lenalidomide-mediated enhanced translation of C/EBPalpha-p30 protein up-regulates expression of the antileukemic microRNA-181a in acute myeloid leukemia. Blood. 2013;121(1):159-69.

30. Chen Y, Jacamo R, Konopleva M, Garzon R, Croce C, Andreeff M. CXCR4 downregulation of let-7a drives chemoresistance in acute myeloid leukemia. J Clin Invest. 2013;123(6):2395-407.

31. Seca H, Lima RT, Almeida GM, Sobrinho-Simoes M, Bergantim R, Guimaraes JE, Vasconcelos MH. Effect of miR-128 in DNA damage of HL-60 acute myeloid leukemia cells. Curr Pharm Biotechnol. 2014;15(5):492-502.

32. Feng DD, Zhang $H$, Zhang $P$, Zheng YS, Zhang XJ, Han BW, Luo XQ, Xu L, Zhou H, Qu LH, Chen YQ. Down-regulated miR-331-5p and miR-27a are associated with chemotherapy resistance and relapse in leukaemia. J Cell Mol Med. 2011;15(10):2164-75.

33. Havelange $V$, Ranganathan $P$, Geyer S, Nicolet D, Huang X, Yu X, Volinia S, Kornblau SM, Andreeff M, Croce CM, Marcucci G, Bloomfield CD, Garzon R Implications of the miR-10 family in chemotherapy response of NPM1mutated AML. Blood. 2014;123(15):2412-5.

34. Dai E, Yang F, Wang J, Zhou X, Song Q, An W, Wang L, Jiang W. ncDR: a comprehensive resource of non-coding RNAs involved in drug resistance. Bioinformatics. 2017;33(24):4010-1.

35. Wang H, Li Q, Tang S, Li M, Feng A, Qin L, Liu Z, Wang X. The role of long noncoding RNA HOTAIR in the acquired multidrug resistance to imatinib in chronic myeloid leukemia cells. Hematology. 2017;22(4):208-16.

36. Xue X, Yang YA, Zhang A, Fong KW, Kim J, Song B, Li S, Zhao JC, Yu J. LnCRNA HOTAIR enhances ER signaling and confers tamoxifen resistance in breast cancer. Oncogene. 2016;35(21):2746-55

37. Zhu J, Zhang R, Yang D, Li J, Yan X, Jin K, Li W, Liu X, Zhao J, Shang W, Yu T. Knockdown of long non-coding RNA XIST inhibited doxorubicin resistance in colorectal cancer by upregulation of miR-124 and downregulation of SGK1. Cell Physiol Biochem. 2018;51(1):113-28.

38. Zhu KP, Zhang $C L$, Ma XL, Hu JP, Cai T, Zhang L. Analyzing the interactions of mRNAs and ncRNAs to predict competing endogenous RNA networks in osteosarcoma chemo-resistance. Mol Ther. 2019;27(3):518-30.

39. Xue M, Li G, Fang X, Wang L, Jin Y, Zhou Q. hsa_circ_0081143 promotes cisplatin resistance in gastric cancer by targeting miR-646/CDK6 pathway. Cancer Cell Int. 2019;19:25.

40. Zhou Y, Zheng X, Xu B, Chen L, Wang Q, Deng H, Jiang J. Circular RNA hsa circ_0004015 regulates the proliferation, invasion, and TKI drug resistance of non-small cell lung cancer by miR-1183/PDPK1 signaling pathway. Biochem Biophys Res Commun. 2019;508(2):527-35.

41. Guarnerio J, Bezzi M, Jeong JC, Paffenholz SV, Berry K, Naldini MM, Lo-Coco F, Tay Y, Beck AH, Pandolfi PP. Oncogenic role of fusion-circRNAs derived from cancer-associated chromosomal translocations. Cell. 2016;166(4):1055-6.

42. Delaney G, Jacob S, Featherstone C, Barton M. The role of radiotherapy in cancer treatment: estimating optimal utilization from a review of evidencebased clinical guidelines. Cancer-Am Cancer Soc. 2005;104(6):1129-37.

43. Lee SY, Jeong EK, Ju MK, Jeon HM, Kim MY, Kim CH, Park HG, Han SI, Kang HS. Induction of metastasis, cancer stem cell phenotype, and oncogenic metabolism in cancer cells by ionizing radiation. Mol Cancer. 2017;16(1):10.

44. De Bacco F, Luraghi P, Medico E, Reato G, Girolami F, Perera T, Gabriele P, Comoglio PM, Boccaccio C. Induction of MET by ionizing radiation and its role in radioresistance and invasive growth of cancer. J Natl Cancer Inst. 2011;103(8):645-61. 
45. Wang XC, Du LQ, Tian LL, Wu HL, Jiang XY, Zhang H, Li DG, Wang YY, Wu HY, She Y, Liu QF, Fan FY, Meng AM. Expression and function of miRNA in postoperative radiotherapy sensitive and resistant patients of non-small cell lung cancer. Lung Cancer. 2011;72(1):92-9.

46. Pajic M, Froio D, Daly S, Doculara L, Millar E, Graham PH, Drury A, Steinmann A, de Bock CE, Boulghourjian A, Zaratzian A, Carroll S, Toohey J, O Toole SA, Harris AL, Buffa FM, Gee HE, Hollway GE, Molloy TJ. miR-139-5p modulates radiotherapy resistance in breast cancer by repressing multiple gene networks of DNA repair and ROS defense. Cancer Res. 2018;78(2):501-15.

47. Suh YE, Raulf N, Gaken J, Lawler K, Urbano TG, Bullenkamp J, Gobeil S, Huot J, Odell E, Tavassoli M. MicroRNA-196a promotes an oncogenic effect in head and neck cancer cells by suppressing annexin $A 1$ and enhancing radioresistance. Int J Cancer. 2015;137(5):1021-34.

48. Ke G, Liang L, Yang JM, Huang X, Han D, Huang S, Zhao Y, Zha R, He X, Wu $X$. MiR-181a confers resistance of cervical cancer to radiation therapy through targeting the pro-apoptotic PRKCD gene. Oncogene. 2013;32(25): 3019-27.

49. Chaudhry MA, Kreger B, Omaruddin RA. Transcriptional modulation of micro-RNA in human cells differing in radiation sensitivity. Int J Radiat Biol. 2010;86(7):569-83.

50. Niemoeller OM, Niyazi M, Corradini S, Zehentmayr F, Li M, Lauber K, Belka C. MicroRNA expression profiles in human cancer cells after ionizing radiation. Radiat Oncol. 2011;6:29.

51. Weidhaas JB, Babar I, Nallur SM, Trang P, Roush S, Boehm M, Gillespie E, Slack FJ. MicroRNAs as potential agents to alter resistance to cytotoxic anticancer therapy. Cancer Res. 2007;67(23):11111-6.

52. Chi H, Tsai C, Tsai M, Yeh C, Lin K. Roles of long noncoding RNAs in recurrence and metastasis of radiotherapy-resistant cancer stem cells. Int J Mol Sci. 2017;18(9):1903.

53. Templin T, Paul S, Amundson SA, Young EF, Barker CA, Wolden SL, Smilenov LB. Radiation-induced micro-RNA expression changes in peripheral blood cells of radiotherapy patients. Int J Radiat Oncol Biol Phys. 2011;80(2):549-57.

54. Megiorni F, Gravina GL, Camero S, Ceccarelli S, Del FA, Desiderio V, Papaccio F, McDowell HP, Shukla R, Pizzuti A, Beirinckx F, Pujuguet P, Saniere L, der Aar EV, Maggio R, De Felice F, Marchese C, Dominici C, Tombolini V, Festuccia C, Marampon F. Pharmacological targeting of the ephrin receptor kinase signalling by GLPG1790 in vitro and in vivo reverts oncophenotype, induces myogenic differentiation and radiosensitizes embryonal rhabdomyosarcoma cells. J Hematol Oncol. 2017;10(1):161.

55. Fayda M, Isin M, Tambas M, Guveli M, Meral R, Altun M, Sahin D, Ozkan G, Sanli Y, Isin H, Ozgur E, Gezer U. Do circulating long non-coding RNAs (IncRNAs) (LincRNA-p21, GAS 5, HOTAIR) predict the treatment response in patients with head and neck cancer treated with chemoradiotherapy? Tumour Biol. 2016;37(3):3969-78.

56. Mueller AK, Lindner K, Hummel R, Haier J, Watson DI, Hussey DJ. MicroRNAs and their impact on radiotherapy for cancer. Radiat Res. 2016;185(6):668-77.

57. Liu Q, Huang J, Zhou N, Zhang Z, Zhang A, Lu Z, Wu F, Mo YY. LncRNA loc285194 is a p53-regulated tumor suppressor. Nucleic Acids Res. 2013; 41(9):4976-87.

58. Hu X, Jiang $H$, Jiang $X$. Downregulation of IncRNA ANRIL inhibits proliferation, induces apoptosis, and enhances radiosensitivity in nasopharyngeal carcinoma cells through regulating miR-125a. Cancer Biol Ther. 2017:18(5):331-8.

59. Yang P, Yang Y, An W, Xu J, Zhang G, Jie J, Zhang Q. The long noncoding RNA-ROR promotes the resistance of radiotherapy for human colorectal cancer cells by targeting the p53/miR-145 pathway. J Gastroenterol Hepatol. 2017:32(4):837-45.

60. Zhang H, Hua Y, Jiang Z, Yue J, Shi M, Zhen X, Zhang X, Yang L, Zhou R, WU S. Cancer-associated fibroblast-promoted LncRNA DNM3OS confers radioresistance by regulating DNA damage response in esophageal squamous cell carcinoma. Clin Cancer Res. 2019;25(6):1989-2000.

61. Zhang Y, He Q, Hu Z, Feng Y, Fan L, Tang Z, Yuan J, Shan W, Li C, Hu X, Tanyi JL, Fan Y, Huang Q, Montone K, Dang CV, Zhang L. Long noncoding RNA LINP1 regulates repair of DNA double-strand breaks in triple-negative breast cancer. Nat Struct Mol Biol. 2016;23(6):522-30.

62. Yang $W$, Yu H, Shen Y, Liu Y, Yang Z, Sun T. MiR-146b-5p overexpression attenuates stemness and radioresistance of glioma stem cells by targeting HuR/lincRNA-p21/beta-catenin pathway. Oncotarget. 2016;7(27):41505-26.

63. Li Z, Zhou Y, Tu B, Bu Y, Liu A, Kong J. Long noncoding RNA MALAT1 affects the efficacy of radiotherapy for esophageal squamous cell carcinoma by regulating Cks1 expression. J Oral Pathol Med. 2017;46(8):583-90.
64. Jin C, Yan B, Lu Q, Lin Y, Ma L. The role of MALAT1/miR-1/slug axis on radioresistance in nasopharyngeal carcinoma. Tumour Biol. 2016;37(3): 4025-33.

65. Wang Y, He L, Du Y, Zhu P, Huang G, Luo J, Yan X, Ye B, Li C, Xia P, Zhang G, Tian Y, Chen R, Fan Z. The long noncoding RNA IncTCF7 promotes selfrenewal of human liver cancer stem cells through activation of Wnt signaling. Cell Stem Cell. 2015;16(4):413-25.

66. Adriaens C, Standaert L, Barra J, Latil M, Verfaillie A, Kalev P, Boeckx B, Wijnhoven PW, Radaelli E, Vermi W, Leucci E, Lapouge G, Beck B, van den Oord J, Nakagawa S, Hirose T, Sablina AA, Lambrechts D, Aerts S, Blanpain C, Marine JC. p53 induces formation of NEAT1 IncRNA-containing paraspeckles that modulate replication stress response and chemosensitivity. Nat Med. 2016;22(8):861-8

67. Wang L, Bu P, Ai Y, Srinivasan T, Chen HJ, Xiang K, Lipkin SM, Shen X. A long non-coding RNA targets microRNA miR-34a to regulate colon cancer stem cell asymmetric division. Elife. 2016;5:e14620.

68. Tang Q, Hann SS. HOTAIR: an oncogenic long non-coding RNA in human cancer. Cell Physiol Biochem. 2018;47(3):893-913.

69. Wong NK, Huang CL, Islam R, Yip SP. Long non-coding RNAs in hematological malignancies: translating basic techniques into diagnostic and therapeutic strategies. J Hematol Oncol. 2018;11(1):131.

70. Calatayud D, Dehlendorff C, Boisen MK, Hasselby JP, Schultz NA, Werner J, et al. Tissue MicroRNA profiles as diagnostic and prognostic biomarkers in patients with resectable pancreatic ductal adenocarcinoma and periampullary cancers. Biomark Res. 2017:5(1):8.

71. Herrera VL, Colby AH, Ruiz-Opazo N, Coleman DG, Grinstaff MW. Nucleic acid nanomedicines in Phase II/III clinical trials: translation of nucleic acid therapies for reprogramming cells. Nanomedicine-Uk. 2018;13(16):2083-98.

72. Bartel DP. MicroRNAs: genomics, biogenesis, mechanism, and function. Cell. 2004;116(2):281-97.

73. Li Z, Rana TM. Therapeutic targeting of microRNAs: current status and future challenges. Nat Rev Drug Discov. 2014;13(8):622-38.

74. Rupaimoole R, Calin GA, Lopez-Berestein G, Sood AK. miRNA deregulation in cancer cells and the tumor microenvironment. Cancer Discov. 2016:6(3): 235-46.

75. Choi YJ, Lin CP, Ho JJ, He X, Okada N, Bu P, Zhong Y, Kim SY, Bennett MJ, Chen C, Ozturk A, Hicks GG, Hannon GJ, He L. miR-34 miRNAs provide a barrier for somatic cell reprogramming. Nat Cell Biol. 2011;13(11):1353-60.

76. Iwagami Y, Zou J, Zhang H, Cao K, Ji C, Kim M, Huang CK. Alcohol-mediated miR-34a modulates hepatocyte growth and apoptosis. J Cell Mol Med. 2018; https://doi.org/10.1111/jcmm.13681

77. Kelnar K, Peltier HJ, Leatherbury N, Stoudemire J, Bader AG. Quantification of therapeutic miRNA mimics in whole blood from nonhuman primates. Anal Chem. 2014;86(3):1534-42.

78. Taieb J, Tabernero J, Mini E, Subtil F, Folprecht G, Van Laethem JL, Thaler J, Bridgewater J, Petersen LN, Blons H, Collette L, Van Cutsem E, Rougier P, Salazar R, Bedenne L, Emile JF, Laurent-Puig P, Lepage C. Oxaliplatin, fluorouracil, and leucovorin with or without cetuximab in patients with resected stage III colon cancer (PETACC-8): an open-label, randomised phase 3 trial. Lancet Oncol. 2014;15(8):862-73.

79. Arunkumar G, Deva MRA, Manikandan M, Prasanna SRH, Subbiah S, llangovan R, Murugan AK, Munirajan AK. Dysregulation of miR-200 family microRNAs and epithelial-mesenchymal transition markers in oral squamous cell carcinoma. Oncol Lett. 2018;15(1):649-57.

80. Lin CY, Hsieh PL, Liao YW, Peng CY, Lu MY, Yang CH, Yu CC, Liu CM. Berberine-targeted miR-21 chemosensitizes oral carcinomas stem cells. Oncotarget. 2017;8(46):80900-8.

81. Liu C, Zhang Y, She X, Fan L, Li P, Feng J, et al. A cytoplasmic long noncoding RNA LINC00470 as a new AKT activator to mediate glioblastoma cell autophagy. J Hematol Oncol. 2018;11(1):77.

82. Li Y, Zeng C, Hu J, Pan Y, Shan Y, Liu B, et al. Long non-coding RNA-SNHG7 acts as a target of miR-34a to increase GALNT7 level and regulate PI3K/Akt/ mTOR pathway in colorectal cancer progression. J Hematol Oncol. 2018; 11(1):89.

83. Khvorova A, Watts JK. The chemical evolution of oligonucleotide therapies of clinical utility. Nat Biotechnol. 2017;35(3):238-48.

84. Amodio N, Raimondi L, Juli G, Stamato MA, Caracciolo D, Tagliaferri P, et al. MALAT1: a druggable long non-coding RNA for targeted anti-cancer approaches. J Hematol Oncol. 2018;11(1):63.

85. Arun G, Diermeier S, Akerman M, Chang KC, Wilkinson JE, Hearn S, Kim Y, MacLeod AR, Krainer AR, Norton L, Brogi E, Egeblad M, Spector DL. 
Differentiation of mammary tumors and reduction in metastasis upon Malat1 IncRNA loss. Genes Dev. 2016;30(1):34-51.

86. Gong N, Teng X, Li J, Liang XJ. Antisense oligonucleotide-conjugated nanostructure-targeting IncRNA MALAT1 inhibits cancer metastasis. ACS Appl Mater Interfaces. 2018. https://doi.org/10.1021/acsami.8b18288.

87. Yap KL, Li S, Munoz-Cabello AM, Raguz S, Zeng L, Mujtaba S, Gil J, Walsh MJ, Zhou MM. Molecular interplay of the noncoding RNA ANRIL and methylated histone $\mathrm{H} 3$ lysine 27 by polycomb CBX7 in transcriptional silencing of INK4a. Mol Cell. 2010;38(5):662-74.

88. Dimitrova N, Zamudio JR, Jong RM, Soukup D, Resnick R, Sarma K, Ward AJ, Raj A, Lee JT, Sharp PA, Jacks T. LincRNA-p21 activates p21 in cis to promote Polycomb target gene expression and to enforce the G1/S checkpoint. Mol Cell. 2014;54(5):777-90.

89. Biroccio A, Leonetti C, Zupi G. The future of antisense therapy: combination with anticancer treatments. Oncogene. 2003;22(42):6579-88.

90. Bai Y, Wong KY, Fung TK, Chim CS. High applicability of ASO-RQPCR for detection of minimal residual disease in multiple myeloma by entirely patient-specific primers/probes. J Hematol Oncol. 2016;9(1):107.

91. Crooke ST. Molecular mechanisms of antisense oligonucleotides. Nucleic Acid Ther. 2017;27(2):70-7.

92. Kurreck J, Wyszko E, Gillen C, Erdmann VA. Design of antisense oligonucleotides stabilized by locked nucleic acids. Nucleic Acids Res. 2002;30(9):1911-8.

93. Ostergaard ME, Hrdlicka PJ. Pyrene-functionalized oligonucleotides and locked nucleic acids (LNAs): tools for fundamental research, diagnostics, and nanotechnology. Chem Soc Rev. 2011;40(12):5771-88.

94. Mah JK. An Overview of recent therapeutics advances for Duchenne muscular dystrophy. Methods Mol Biol. 2018;1687:3-17.

95. Inoue $\mathrm{S}$, Patil R, Portilla-Arias J, Ding H, Konda B, Espinoza A, Mongayt D, Markman JL, Elramsisy A, Phillips HW, Black KL, Holler E, Ljubimova JY. Nanobiopolymer for direct targeting and inhibition of EGFR expression in triple negative breast cancer. Plos One. 2012;7(2):e31070.

96. Chang RM, Xiao S, Lei X, Yang H, Fang F, Yang LY. miRNA-487a promotes proliferation and metastasis in hepatocellular carcinoma. Clin Cancer Res. 2017;23(10):2593-604.

97. Sekhon HS, London CA, Sekhon M, Iversen PL, Devi GR. C-MYC antisense phosphosphorodiamidate morpholino oligomer inhibits lung metastasis in a murine tumor model. Lung Cancer. 2008;60(3):347-54.

98. El FR, Subramanian S, Uhlmann EJ, Krichevsky AM. Genome editing reveals glioblastoma addiction to microRNA-10b. Mol Ther. 2017;25(2):368-78.

99. Gutschner T, Hammerle M, Eissmann M, Hsu J, Kim Y, Hung G, Revenko A, Arun G, Stentrup M, Gross M, Zornig M, MacLeod AR, Spector DL, Diederichs $\mathrm{S}$. The noncoding RNA MALAT1 is a critical regulator of the metastasis phenotype of lung cancer cells. Cancer Res. 2013;73(3):1180-9.

100. Iversen PL, Arora V, Acker AJ, Mason DH, Devi GR. Efficacy of antisense morpholino oligomer targeted to c-myc in prostate cancer xenograft murine model and a phase I safety study in humans. Clin Cancer Res. 2003; 9(7):2510-9.

101. Lee K, Jang B, Lee YR, Suh EY, Yoo JS, Lee MJ, Lee JY, Lee H. The cuttingedge technologies of siRNA delivery and their application in clinical trials. Arch Pharm Res. 2018;41(9):867-74.

102. Knott GJ, Doudna JA. CRISPR-Cas guides the future of genetic engineering Science. 2018;361 (6405):866-9.

103. Cao S, Chen G, Yan L, Li L, Huang X. Contribution of dysregulated circRNA_ 100876 to proliferation and metastasis of esophageal squamous cell carcinoma. Onco Targets Ther. 2018;11:7385-94.

104. Zorde KE, Gabai R, Rachmut IH, Horwitz E, Brunschwig Z, Orbach A, Shemi A, Golan T, Domb AJ, Yavin E, Giladi H, Rivkin L, Simerzin A, Eliakim R, Khalaileh A, Hubert A, Lahav M, Kopelman Y, Goldin E, Dancour A, Hants Y, Arbel-Alon S, Abramovitch R, Shemi A, Galun E. Mutant KRAS is a druggable target for pancreatic cancer. Proc Natl Acad Sci U S A. 2013;110(51):20723-8.

105. Golan T, Khvalevsky EZ, Hubert A, Gabai RM, Hen N, Segal A, Domb A, Harari G, David EB, Raskin S, Goldes Y, Goldin E, Eliakim R, Lahav M, Kopleman Y, Dancour A, Shemi A, Galun E. RNAi therapy targeting KRAS in combination with chemotherapy for locally advanced pancreatic cancer patients. Oncotarget. 2015;6(27):24560-70.

106. Reebye V, Saetrom P, Mintz PJ, Huang KW, Swiderski P, Peng L, Liu C, Liu X, Lindkaer-Jensen S, Zacharoulis D, Kostomitsopoulos N, Kasahara N, Nicholls JP, Jiao LR, Pai M, Spalding DR, Mizandari M, Chikovani T, Emara MM, Haoudi A, Tomalia DA, Rossi JJ, Habib NA. Novel RNA oligonucleotide improves liver function and inhibits liver carcinogenesis in vivo. Hepatology. 2014;59(1):216-27.
107. Reebye V, Huang KW, Lin V, Jarvis S, Cutilas P, Dorman S, Ciriello S, Andrikakou P, Voutila J, Saetrom P, Mintz PJ, Reccia I, Rossi JJ, Huber H, Habib R, Kostomitsopoulos N, Blakey DC, Habib NA. Gene activation of CEBPA using saRNA: preclinical studies of the first in human saRNA drug candidate for liver cancer. Oncogene. 2018;37(24):3216-28.

108. Wen J, Tao W, Hao S, Zu Y. Cellular function reinstitution of offspring red blood cells cloned from the sickle cell disease patient blood post CRISPR genome editing. J Hematol Oncol. 2017;10(1):119.

109. Yamauchi T, Masuda T, Canver MC, Seiler M, Semba Y, Shboul M, Al-Raqad M, Maeda M, Schoonenberg V, Cole MA, Macias-Trevino C, Ishikawa Y, Yao Q, Nakano M, Arai F, Orkin SH, Reversade B, Buonamici S, Pinello L, Akashi K, Bauer DE, Maeda T. Genome-wide CRISPR-Cas9 screen identifies leukemiaspecific dependence on a pre-mRNA metabolic pathway regulated by DCPS. Cancer Cell. 2018;33(3):386-400.

110. Hu B, Zou Y, Zhang L, Tang J, Niedermann G, Firat E, Huang X, Zhu X. Nucleofection with plasmid DNA for CRISPR/Cas9-mediated inactivation of programmed cell death protein 1 in CD133-specific CAR T cells. Hum Gene Ther. 2019;30(4):446-58.

111. Jung IY, Kim YY, Yu HS, Lee M, Kim S, Lee J. CRISPR/Cas9-mediated knockout of DGK improves antitumor activities of human T cells. Cancer Res. 2018;78(16):4692-703.

112. Yoon PO, Park JW, Lee CM, Kim SH, Kim HN, Ko Y, Bae SJ, Yun S, Park $J$ H, Kwon T, Kim WS, Lee J, Lu Q, Kang HR, Cho WK, Elias JA, Yang JS, Park HO, Lee K, Lee CG. Self-assembled micelle interfering RNA for effective and safe targeting of dysregulated genes in pulmonary fibrosis. J Biol Chem. 2016;291(12):6433-46.

113. Solmesky $\amalg$, Shuman M, Goldsmith M, Weil M, Peer D. Assessing cellular toxicities in fibroblasts upon exposure to lipid-based nanoparticles: a high content analysis approach. Nanotechnology. 2011;22(49):494016.

114. Huang JL, Chen HZ, Gao XL. Lipid-coated calcium phosphate nanoparticle and beyond: a versatile platform for drug delivery. J Drug Target. 2018;26(56):398-406.

115. Huang KW, Lai YT, Chern GJ, Huang SF, Tsai CL, Sung YC, Chiang CC, Hwang PB, Ho TL, Huang RL, Shiue TY, Chen Y, Wang SK. Galactose derivative-modified nanoparticles for efficient siRNA delivery to hepatocellular carcinoma. Biomacromolecules. 2018;19(6):2330-9.

116. Yagishita S, Fujita Y, Kitazono S, Ko R, Nakadate Y, Sawada T, Kitamura Y, Shimoyama T, Maeda Y, Takahashi F, Takahashi K, Tamura T, Koizumi F. Chemotherapy-regulated microRNA-125-HER2 pathway as a novel therapeutic target for trastuzumab-mediated cellular cytotoxicity in small cell lung cancer. Mol Cancer Ther. 2015;14(6):1414-23.

117. Daugaard I, Knudsen A, Kjeldsen TE, Hager H, Hansen LL. The association between miR-34 dysregulation and distant metastases formation in lung adenocarcinoma. Exp Mol Pathol. 2017;102(3):484-91.

118. Chen W, Zhou Y, Zhi X, Ma T, Liu H, Chen BW, Zheng X, Xie S, Zhao B, Feng $X$, Dang $X$, Liang T. Delivery of miR-212 by chimeric peptide-condensed supramolecular nanoparticles enhances the sensitivity of pancreatic ductal adenocarcinoma to doxorubicin. Biomaterials. 2019;192:590-600.

119. Liu YA, Zhang Y, Zheng Z, Li K, Wu XH, Du QG, Ye X, Wang L, Zhu L. MicroRNA-216b reduces growth, migration and invasion of pancreatic ductal adenocarcinoma cells by directly targeting rho-associated coiled-coil containing protein kinase 1. Oncol Lett. 2018;15(5):6745-51.

120. Li Y, Duo Y, Zhai P, He L, Zhong K, Zhang Y, Huang K, Luo J, Zhang H, Yu X. Dual targeting delivery of miR-328 by functionalized mesoporous silica nanoparticles for colorectal cancer therapy. Nanomedicine (Lond). 2018; https://doi.org/10.2217/nnm-2017-0353.

121. Li F, Wang F, Zhu C, Wei Q, Zhang T, Zhou YL. miR-221 suppression through nanoparticle-based miRNA delivery system for hepatocellular carcinoma therapy and its diagnosis as a potential biomarker. Int J Nanomedicine. 2018;13:2295-307.

122. Nair JK, Willoughby JL, Chan A, Charisse K, Alam MR, Wang Q, Hoekstra M, Kandasamy P, Kel'In AV, Milstein S, Taneja N, O'Shea J, Shaikh S, Zhang L, van der Sluis RJ, Jung ME, Akinc A, Hutabarat R, Kuchimanchi S, Fitzgerald K, Zimmermann T, van Berkel TJ, Maier MA, Rajeev KG, Manoharan M. Multivalent $\mathrm{N}$-acetylgalactosamine-conjugated siRNA localizes in hepatocytes and elicits robust RNAi-mediated gene silencing. J Am Chem Soc. 2014;136(49):16958-61.

123. Spiess M. The asialoglycoprotein receptor: a model for endocytic transport receptors. Biochemistry-Us. 1990;29(43):10009-18.

124. Foster DJ, Brown CR, Shaikh S, Trapp C, Schlegel MK, Qian K, Sehgal A, Rajeev KG, Jadhav V, Manoharan M, Kuchimanchi S, Maier MA, Milstein S. 
Advanced siRNA designs further improve in vivo performance of GalNAcsiRNA conjugates. Mol Ther. 2018;26(3):708-17.

125. Lv H, Zhang S, Wang B, Cui S, Yan J. Toxicity of cationic lipids and cationic polymers in gene delivery. J Control Release. 2006;114(1):100-9.

126. Moschos SA, Jones SW, Perry MM, Williams AE, Erjefalt JS, Turner JJ, Barnes PJ, Sproat BS, Gait MJ, Lindsay MA. Lung delivery studies using siRNA conjugated to TAT(48-60) and penetratin reveal peptide induced reduction in gene expression and induction of innate immunity. Bioconjug Chem. 2007;18(5):1450-9.

127. Baker A, Aguirre-Hernández C, Halldén G, Parker A. Designer oncolytic adenovirus: coming of age. Cancers. 2018;10(6):201.

128. Heise C, Hermiston T, Johnson L, Brooks G, Sampson-Johannes A, Williams A, Hawkins L, Kirn D. An adenovirus E1A mutant that demonstrates potent and selective systemic anti-tumoral efficacy. Nat Med. 2000;6(10):1134-9.

129. Qian C, Campidelli A, Wang Y, Cai H, Venard V, Jeulin H, Dalle JH, Pochon C, D'Aveni M, Bruno B, Paillard C, Vigouroux S, Jubert C, Ceballos P, Marie-Cardine A, Galambrun C, Cholle C, Clerc UI, Petitpain N, De Carvalho BM, Decot V, Reppel L, Salmon A, Clement L, Bensoussan D. Curative or pre-emptive adenovirus-specific $T$ cell transfer from matched unrelated or third party haploidentical donors after HSCT, including UCB transplantations: a successful phase 1/II multicenter clinical trial. J Hematol Oncol. 2017;10(1):102.

130. Machitani M, Sakurai F, Wakabayashi K, Tachibana M, Fujiwara T, Mizuguchi $\mathrm{H}$. Enhanced oncolytic activities of the telomerase-specific replicationcompetent adenovirus expressing short-hairpin RNA against dicer. Mol Cancer Ther. 2017;16(1):251-9.

Ready to submit your research? Choose BMC and benefit from:

- fast, convenient online submission

- thorough peer review by experienced researchers in your field

- rapid publication on acceptance

- support for research data, including large and complex data types

- gold Open Access which fosters wider collaboration and increased citations

- maximum visibility for your research: over $100 \mathrm{M}$ website views per year

At $\mathrm{BMC}$, research is always in progress.

Learn more biomedcentral.com/submissions 